

\title{
BERGMAN Y ROSSELLINI FRENTE A LA TV
}

\author{
BERGMAN AND ROSSELLINI IN FRONT OF THE TV
}

Juan A. Hernández Les

Universidad Santiago de Compostela

\section{Resumen:}

La fe y la esperanza que Ingmar Bergamn y Roberto Rossellini depositaron en el mundo de la televisión produjo en la obra de ambos directores singulares filmes que posteriormente han podido verse en las salas tradicionales del cine, aunque no siempre. Para Bergman no había ninguna diferencia entre el cine y la televisión, mientras que para Rosselllini en un principio sí, aunque más tarde tendió a subsumir los dos lenguajes en uno solo. La semilla que ambos plantaron en esta dialéctica visual ejerció una gran influencia en la historia del cine. Paradójicamente hoy la autoría y la televisión, salvo raras excepciones, no parece producir grandes encuentros.

\begin{abstract}
:
Faith and hope Ingmar Rossellini Bergan deposited in the TV world was in the work of two unique film directors who have subsequently been seen in traditional cinema halls, but not always. For Bergman, there was no difference between cinema and television, while for other Rosselllini at first, but later tended to subsume the two languages __into one. The seed planted both in this visual dialectic exerted a great influence on the history of cinema. Ironically today the author and television, with rare exceptions, there seems to produce great games.
\end{abstract}

\section{Palabras clave:}

Televisión, Bergman, Rossellini, Saraband, Sócrates, paradigmas, Secretos de un matrimonio

Key words:

TV, Bergman, Rossellini, Saraband, Socrates, paradigms, Scenes from a Marriage 


\section{Cierta teoría de la ficción}

Las soluciones ejemplares de los problemas, dice Kuhn, constituyen uno de los vehículos esenciales del contenido cognoscitivo de una teoría (Kuhn, 1975). Un paradigma vendría a ser una generalización verbal y simbólica junto con ejemplos de su funcionamiento en la práctica. Un paradigma puede dirigir una investigación, incluso sin reglas, añadía (Kuhn, 1975: 79).

Bazin, el padre de la crítica moderna, decía que el cine era la culminación histórica del realismo ${ }^{1}$; es decir, que el cine satisfaría una vieja aspiración de las artes narrativas y visuales que lo habían precedido. El realismo en el cine hay que entenderlo desde una visión ontológica, término que no se ha comprendido bien, y que se ha explicado peor. La impresión de realidad en el cine es diferente a la que parte de otras imágenes visuales, porque realmente lo representado en una pantalla no es sólo lo que se representa, sino que además es representación. Es decir, percibimos la imagen como una instancia del espacio en el que el espectador entra dentro del escenario representado, actuando a la vez junto a los actantes que se mueven a través de ese mismo escenario. Frente a la imagen fotográfica, la imagen fílmica nos instala dentro del circuito visual; entramos dentro de la pantalla y tocamos a nuestros personajes, de manera que la ontología fílmica se define precisamente por situarnos ante dos planos que se superponen. El plano de la realidad (a Wayne podríamos tocarlo y está allí dentro, vivo) y el plano de la conciencia: una imagen en movimiento es el resultado de un milagro químico y tecnológico, que se parece a un sueño, pero que es más real que el sueño ya que también estamos fuera de la pantalla, sentados en una butaca, observando y recorriendo el espacio visual que se halla frente a nosotros. Según Frank Mc Connell el cine es la más real e irreal de todas las artes (Mc Connell, 1977).

La imagen cinematográfica, y por extensión en nuestro estudio, la televisiva, actúa dentro del campo de la estética, cuyo principal objeto de estudio ha sido históricamente la relación entre el arte y lo real. Sartre, como buen fenomenólogo estudió este conflicto y concluyó que nada que tenga que ver con lo artístico tiene que ver con lo real (Osborne, 1972). Se denomina ficción

\footnotetext{
${ }_{1}$ Cfr. (BAZIN, 1962) Al mismo tiempo que definía esta opinión desarrollaba su idea del cine como ontología, aspecto que posteriormente nadie ha desarrollado.
} 
televisiva a los programas de series dramáticas que han sido escritas y producidas para la televisión, y la gente pone los ejemplos de Los Soprano, El ala oeste de la Casa Blanca o A dos metros bajo tierra.

Todo esto tuvo al principio unos orígenes canónicos y de una inmensa dignidad cuando algunos cineastas de renombre, como es el caso que nos reúne, decidieron trabajar para la televisión. Los motivos de Rossellini y de Bergman fueron, en todo caso, muy diferentes; como diferentes fueron los medios que utilizaron y los fines alcanzados. Rossellini, por sobrevivir. Bergman, como una extensión natural de su actividad artística. Pero la supervivencia llevó a Rossellini al descubrimiento de que era posible vincular el cine y la vida, la Historia como conocimiento, y la virtud y la verdad. Mientras que la versatilidad de Bergman nos reveló que la calidad de la imagen puede reivindicarse en la televisión si quien la trata es respetuoso con ciertos principios narrativos, cierto canon visual y cierta autoría. Sorprendentemente, el cine histórico condujo a Rossellini a cierta ampulosidad visual, mientras que la televisión transformó a Bergman en un realizador austero. Rossellini hizo televisión con el objetivo de hacer grandes filmes, y Bergman hizo televisión con la finalidad de ser sencillo y didáctico. Mientras Rossellini hizo sus filmes televisivos filmando como un cineasta, Bergman hizo los suyos como si fuera un realizador de televisión, a excepción de Fanny y Alexander, en donde el director sueco compone la puesta en escena pensando que la película acabará siendo un producto de consumo para el cine y para la televisión. Por eso, lo mejor es aislar del resto del conjunto tres filmes que funcionan como paradigmas de una visión diferente. Bergman se sirve de la televisión para hacer televisión, y Rossellini se sirve de la televisión para hacer cine, aunque ambos trabajan con un material que hoy ya nadie emplearía: la película de $16 \mathrm{~mm}$, en los primeros casos, y la alta definición en el último.

Cabría hablar todavía de un cineasta que no pudo experimentar del todo el nuevo medio aun cuando creía en sus inmensas posibilidades: Jean Renoir (Romaguera, 1985), director que llevó al Dr. Jeckyll hasta las mismísimas butacas de las salas de estar en El testamento del Dr. Cordelier, 1961, versión en la que el médico es un contemporáneo nuestro. En cierto sentido Rossellini y Bergman aplicarían la vieja tesis de Renoir sobre el significado de la cámara: la 
cámara sólo tiene un derecho, el de registrar lo que ocurre. En todo caso la primera fascinación de estos cineastas frente a la televisión derivaba de unas observaciones que se han dejado de hacer. Cuando Renoir conoció la televisión americana descubrió que los primeros planos de las entrevistas en directo eran riquísimos porque no estaban elaborados. La técnica "televisiva" que Bergman utiliza en Secretos de un matrimonio, con todo, se enriquece enormemente gracias a dos actores magistrales. La televisión se había atrevido a salir a la búsqueda del hombre, decía Rossellini. Era su momento fundacional, su momento clásico. La televisión se dirigía a diez millones de individuos, no a un grupo constituido por la masa de esos diez millones. Rossellini pensaba porque había fracasado ante el gran público del cine, pero no ante los públicos pequeños del cine.club. Diario de una camarera, 1946, fracasó en el cine, pero fue un éxito en la televisión.

Una novela de 1951, Fahrenheit 451, de Ray Bradbury, nos indicaba una sociedad en que las paredes de las casas eran pantallas que dirigían los pasos y el pensamiento de sus habitantes, aunque con una pequeña diferencia frente a las pantallas caseras de hoy, incluyendo Internet, la Gran Pantalla: y es que sus productores y dirigentes ya saben para qué se han inventado: para reunir allí todos los mensajes posibles, especialmente los persuasivos, es decir, los dedicados a vender productos para cerrar y completar el circuito del consumo. Además el único publico que le interesa a la televisión es aquel público moldeable y fácil, de tal manera que la llamada telebasura no es un programa, sino una tendencia generalista que se ha impuesto como un canon que amenaza con invadir hostilmente las sensibles alambradas de la televisión de pago, cada vez más deteriorada.

Si la ficción es la mirada que ponemos sobre una imagen y no la imagen misma, habría que reconocer, con Godard, que la ficción es tan real como el documento, que es un momento distinto de la realidad. Mi impresión a este respecto es que las personas no vivimos de convicciones, sino de ilusiones. El trato permanente con nuestras ilusiones nos lleva directamente al trato con el destino, con los objetivos, hasta el punto de que en ese instante hacemos que nosotros mismos nos convirtamos en personajes de ficción, y que toda nuestra vida sea, en el fondo, tan ficticia, como la vida de Jean Valjean en Los miserables. Rossellini y 
Bergman al filmar filman lo que hay entre las cosas, lo que hay entre las personas, y entre la Historia y las personas. Esto es creatividad.

El tiempo aclara mucho las cosas. Hoy la novela citada me parece más una crónica de la Historia de Francia que una novela de ficción. Todas nuestras experiencias son de carácter visual, esto es, experiencias de segunda mano. La vida actual está dominada por un gran género, el docudrama, la televisión del fingimiento. De forma sutil se pueden manipular los sentimientos de las gentes recurriendo a imágenes de archivo. Estas imágenes se reproducen aleatoriamente. Da igual a qué día pertenezcan, en qué día fueran tomadas. El público las consume en forma de una serie interminable sobre el mal si tratan de la guerra de Irak. Una imagen ideológicamente repetida pasa a constituir de inmediato una genealogía de la ficción quedando eliminada como documento. Hoy toda la televisión que se hace es fingimiento en el momento en que el técnico de turno echa mano de la llave del archivo para contaminar el cóctel explosivo de las 3.0o h. Esto tiene una frase: no es creatividad, sino mentira.

¿Cómo se ha llegado a esto? Muy fácilmente: habiendo descubierto que la fenomenología televisiva es el directo. La televisión sale siempre en directo en las pantallas, incluso cuando sus imágenes son retrospectivas. Si tú sacas la foto de las Azores una y otra vez lo que obtienes es un directo constante y permanente. Mientras saques esta foto el presente social de referencia te llevará a ganar todas las elecciones que tú quieras. Lo único que necesitas es que la foto no se estropee en los archivos y que la guerra de Irak no se acabe. Tanto es así que probablemente cuando los suicidas dejen de suicidar a los demás, los espectadores no nos enteraremos por algún tiempo de que aquello ha terminado. Esto no es creatividad, sino mentira.

Lacan no se hacía ilusiones cuando distinguía lo real, lo imaginario y lo simbólico. Podía definir los dos últimos términos pero reconocía que lo real se le escapaba de las manos, ya que pertenecía al ámbito de fuera-de-significado, Das ding (la cosa) (Requena, 2003). En cualquier caso lo real sería aquello que no se puede decir, ni expresar ni representar, porque de hacerlo perdería su verdadera esencia. Lo real está siempre presente pero continuamente mediatizado por lo imaginario y lo simbólico. Lo imaginario vendría a ser un aspecto no lingüístico de la psique, y lo simbólico el discurso por el cual el sujeto materializa sus 
deseos. Algunos japoneses fueron encontrados en la selva 40 años después de que hubiera acabado la guerra porque para ellos la guerra era también el presente social de referencia del que hablara Gomis. Hegel escribió en sus diarios que tengo que hallar una verdad para mí, encontrar esa idea por la que quiero vivir y morir. La invisibilidad entre ficción y personalismo descansa en la idea de que lo personal es lo real, que tanta influencia tendrá progresivamente en los existencialistas posteriores: el hombre se elige a sí mismo como existente, vive en el dominio de lo que Schiller denominó el estadio estético, un estadio en donde el único compromiso que se puede y debe atender es la momentaneidad.

Yo tengo una serie de ilusiones y las organizo plásticamente de tal forma que son vistas y analizadas por otros que carecen de ilusiones porque no les gusta verse como personajes. Pertenecen a la categoría de las no personas. Y entonces van y dicen que yo soy el japonés de la selva que cree en la ficción. Naturalmente las diferencias entre las justas ilusiones y las aberraciones ficticias o fingidas es que el objetivo de éstos no es otro que el de escapar a la verdad.

Cuando Borges escribió, demostrándolo, que Pierre Menard era el autor de $E l$ Quijote, estaba ensayando una ilusión fantástica, irreal, aterrorizadora, pero atribuible ya que El Quijote es una ficción, ¿en donde hallaríamos lo real? ¿Por qué aceptamos que Stromboli sea un filme y no un documental? Sólo por una cosa: por la presencia de Ingrid Bergman. ¿Pero no es Ingrid Bergman una imagen movimiento, una imagen tiempo? ¿Qué grado de realidad concedemos a una imagen?

Si analizamos el problema fríamente la televisión no sólo ha secuestrado millones de espectadores a las salas, sino que además ha reducido progresivamente su parque de una manera que llevó a ciertos maoístas a profetizar la muerte del cine (Lenne, 1971). Jean R. Debrix ya se planteó hace años cómo tendrían que formalizarse las nuevas relaciones entre ambos medios, y si uno vencería sobre el otro, o si fundarían una especie de analogía y acuerdo canónico que permitiera la supervivencia de ambos (Debrix, 1980). Allí en donde hay televisión se ha producido un cambio considerable, pero hay países, como la India, que produce más cine que Hollywood y, también, más ingenieros en términos porcentuales. 
En los años 70 cuando se hablaba de la televisión todo quedaba reducido a las relaciones con el cine. No se contemplaba la evolución de la televisión desde la perspectiva de la oferta, del análisis de las audiencias, de la publicidad, de la aparición de las cadenas privadas y, especialmente, de la programación, hoy exhaustiva y delirante. Se pensaba que la puesta en escena era la misma que la del cine. Se pensaba que un espectador de televisión era como el lector de un libro. Lo único cierto es que la televisión que se hace es cada vez peor. Y que lo único que acerca a los dos medios es la tecnología, pues ahora las imágenes prácticamente ya se imprimen igual. Se llegó incluso a hablar de escuela y televisión, como si ésta fuera capaz de cumplir una función educativa en el tercer mundo. Se hablaba de la introducción de la televisión en las escuelas y en los países en donde no hubiera maestros, a la manera en que hoy se habla de Internet como instrumento incorporado y extendido en la escuela primaria y secundaria.

\section{Rossellini y la televisión}

Se arguye en demasía que el cine de Rossellini para la TV tenía una finalidad didáctica (Quintana, 1996), como si intentara lograr un acuerdo entre la imagen y la palabra, pero esto ya estaba en sus películas anteriores. Además, qué otra forma había de trasladar a Sócrates si no se hacía por medio de los diálogos platónicos. En sus once películas para la televisión, casi todas rodadas en 16 $\mathrm{mm}$, Rossellini se interesa por hombres que modificaron el curso de las cosas, desde Agustín de Hipona hasta Luis XIV, pasando por Cosimo de Médici o Descartes. Adriano Aprá desmintió esas cuestiones en su crítica de Cahiers al sostener en relación a La edad del hierro que Rossellini no quería desvelar una verdad, ya que determinar una verdad equivaldría a eliminar otra tal vez más esencial.

La actitud de Rossellini frente al cine y a la vida fue siempre muy socrática. La capacidad de Rossellini, como la de todos los grandes narradores consiste en haber sabido adaptar trozos del Banquete, de la Apología y más, sutilmente de La República, haciendo de Sócrates un todo infranqueable. Rossellini, como Platón, creía más en las palabras que en la escritura (Lledó, 1992). La palabra es siempre dialéctica, siempre democrática, mientras que la escritura es 
impositiva, cerrada, autoritaria. Ya decía Barthes que existían una escritura burguesa, y otra revolucionaria (Barthes, 1972). Por lo tanto, el cine sería para Rossellini un tercer sentido, un grado cero de la imagen. Rossellini defendía la pasión por la elocuencia, ya que era la única forma de alcanzar la verdad: primero, haciéndole ver a su interlocutor la verdad de una cosa; después, haciéndole ver la cosa contraria. Esa es la verdadera elocuencia.

Con este filme nadie osó ir más lejos en una crítica al autoritarismo. El autoritarismo es la fronda más decisiva de la democracia actual. Y la persuasión, el método más eficazmente expulsado de las relaciones entre los hombres. Un hombre puede ser llevado ante un tribunal a declarar sobre las acusaciones que recaen sobre él, pero nunca para persuadirlo.

Dice Rossellini que "la crisis de hoy no es únicamente crisis del cine, sino también crisis de la cultura. El cine, medio de difusión por excelencia, ha tenido el mérito de hacer palpable esta crisis, ponerla en evidencia. Por eso quise retirarme de la profesión, y pienso que tengo la obligación de prepararme -con toda libertad-para replanteármelo todo desde el principio, y volver a retomar el camino a partir de bases completamente nuevas.

Hay quien cree, como Quintana, que Rossellini se habría preguntado por qué el cine había articulado el esfuerzo sólo hacia el espectáculo y no hacia el conocimiento. A los 57 años Rossellini descubría que quería ser en el cine lo que un maestro es en la escuela: explicar de la manera más simple los grandes hechos de la naturaleza y la Historia. Su teoría no se estrelló contra los caminos seguidos por la televisión de consumo, que también, sino que la televisión resolvió un sistema, el del fraccionamiento, el de las ventanas, que también permitió a muchos iniciarse en el tratamiento del conocimiento.

Lo que no vio Rossellini es que el medio no siempre es neutral o inocente, y que lo que siempre importa es el hombre, como a él le gustaba decir. La televisión tiene ya ventanas dedicadas en exclusiva a enseñar la belleza de la naturaleza, la ecología de las especies animales, el origen del mono, y todo ello ya ha pasado a formar parte de la espectacularización del medio.

La crisis es de la cultura, como él decía, y es del hombre. La crisis es de la propia socialización de la cultura, la socialización de la educación, y de la igualdad intelectual mal entendida. ¿Proponía Rossellini un regreso a la inocencia? El 
filme tiene la posibilidad-decía-de poner en un solo fotograma diez cosas a la vez, pero lo importante son las ideas, no las imágenes. Aristarco acababa de herirle con la opinión de que se había entregado a una de las dos grandes corrientes políticas italianas. Sin embargo, la crítica francesa -Raymond Bellousostenía que Rossellini había eliminado cualquier oposición entre documental y ficción ${ }^{2}$.

El conocimiento es un proceso por el cual lo real se articula con la ilusión. Una entrevista con Rossellini hizo pensar a algunos que el cineasta aplicaba la teoría de Comenio en su forma de conducirse en el cine. El checo Comenio había escrito en Didáctica Magna que la dificultad para aprender proviene del hecho de que las cosas no se enseñan a los alumnos por visión directa, sino por aburridísimas descripciones. Pero Rossellini habla a la vida como si fuera un mesías, desde una cierta superioridad. La superioridad de todo mesías no motiva a desempeñar cargos políticos. Sólo motiva para el lenguaje. El lenguaje tiene algo de teoría de los juegos. Quien lo domina siempre tiene la solución final. Y aquella dialéctica, algo de diabólica.

La pasión de Rossellini por la Historia se acentuó cuando abandonó el cinematógrafo y se volcó hacia la televisión. Sus conocimientos de Historia eran extraordinarios. Fue Rossellini un cineasta historiador por vocación. Admiraba a Luis XIV porque éste tuvo una solución genial para controlar a los nobles y acabar con la Fronda. Vivir de una forma delirante, ya que los tiempos lo eran. Luis XIV construyó Versalles como si escribiera una metáfora, sin percibir siquiera lo que podría llegar a suceder 100 años después. Rossellini se leyó al completo las cartas del Rey. Seguía de nuevo en su lucha por entender el sentido de las palabras. En su crítica de la época, Aldo Bernardino destacaba el hecho de que el cineasta se colocaba ante el rey como un notario que tomara nota objetivamente de los diálogos de cámara, a la manera de un Kamesrpielfilm. José Luis Guarner la consideró como la primera película didáctica de ficción de la historia del cine porque condenaba a todo el cine histórico realizado hasta ese momento (1985: 175).

\footnotetext{
${ }^{2}$ En la película de Jaime Chavarri, $\quad E l$ desencanto , 1974, la primera intención del productor Elías Querejeta fue la de realizar un documental sobre la familia Panero. Hoy se sabe que los Panero interpretaron, representaron y, finalmente, mixtificaron su propia vida en una forma de jocoso engaño que terminó por convertirlos en verdaderos personajes de ficción.
} 
Unas declaraciones de Rossellini realizadas en torno a 1963 no dejan lugar para las dudas a este respecto: la Historia, a través de la enseñanza visual, puede moverse en su terreno, y no volatilizarse en fechas y nombres. Puede abandonar el cuadro de la historia-batalla para constituirse en sus dominantes socioeconómico-políticas. Puede construir no en la vertiente de la fantasía, sino en el de la ciencia histórica, climas, costumbres, ambientes, hombres que tuvieron relieve histórico y promovieron los avances sociales en los que hoy vivimos. Algunos personajes, considerados psicológicamente pueden convertirse, por sus cualidades humanas, en módulos de acción (Guarner, 1973: 175).

Siempre la Historia y la verdad. En 1971 Allende promovió una operación de imagen que denominó verdad. Y allí acudió Rossellini a entrevistarse con el político. La televisión difundió, tras su heroica muerte, aquella entrevista dialógica de los dos hombres. Al recordar aquel encuentro Rossellini, que había comprobado que el Presidente vivía en la calle Tomás Moro, comentó que: el hombre vale por su inteligencia, por su capacidad de entender, por su capacidad de ser absolutamente consciente.

Hubo una vez un hombre que tuvo que luchar toda su vida contra su enfermedad: era Pascal, jansenista e inventor. Borgiano constructor de pensamientos, que también interesó a Rossellini. Era la oportunidad de entrar en el conflicto entre ciencia y religión, como Sócrates había sido la oportunidad de entrar en el conflicto entre política e independencia personal. Para poder informar sobre una época histórica -decía Rossellini- es necesario verla, representarla a través de sus ideas, y de sus hombres.

En este sentido, conviene recordar las palabras que Louis Norman escribiera en 1974: la narración estática y sin dinamismo a menudo hace que sus filmes didácticos sean decepcionantes desde un punto de vista dramático, pero, paradójicamente, su debilidad dramática, se convierte en su fuerza moral y pedagógica.

Rossellini, como Zweig o Chateaubriand, sintió la necesidad de cronificar el paso del tiempo de una época que muere y otra que surge de las cenizas de la anterior. Rossellini afrontó la decadencia en San Agustín, aquel héroe, original y auténtico, que hubo de luchar contra el paganismo moribundo y el donatismo 
reinante. De nuevo un Rossellini que amaba la vida más que el cine, y que amaba a los hombres. La verdad es como un punto en un vastísimo espacio, y que los caminos para llegar a ella son infinitos y convergentes, decía.

Rossellini, que hizo un duro retrato de Descartes en su telefilme, al menos creía que no había mayor satisfacción en la vida que la de pensar. Lamentó que Descartes, asustado por el juicio contra Galileo, ocultara su texto del Discurso del método en 1637. Pero Descartes le permitió volver a la dialéctica socrática y jansenista. Según Sergio Trasatti Descartes nos es restituido en toda su integridad, y el filme se ajusta funcionalmente a esa clase de matices y fracciones visuales que tanto gustaban al director (Arendt, 2005).

\subsection{El Sócrates, paradigma}

La política, dice el personaje rosselliniano, no debería ser el arte de dominar, sino el arte de enseñar a todos la justicia, tan impregnado estaba de las enseñanzas del maestro. La locura y el crimen son la misma cosa, añade. En aquella época los griegos colocaban la salud como la primera de las buenas cosas. Antes de la belleza, y ésta antes de la riqueza, pero Sócrates negaba esta triada, pues la mayor felicidad que podemos encontrar los hombres es la felicidad de ser justo. Es muy interesante este comienzo tan expansivo. Los que hacen el mal son locos. El mal es una folía.

¿La riqueza, el dominio sobre otros hombres? Pero cuando pierdan ese poder ¿Qué les quedará? Sólo el recuerdo de los crímenes que cometieron, y ¿qué más? Una ignorancia que sólo las ilusiones del poder velaron a sus ojos. ¿Y qué otra razón puede haber para sus crímenes, si no tal ignorancia que les mantiene en un estado de perpetua ansiedad?

Sócrates parece anticiparse al carácter de San Juan Bautista, personaje que recrea en El Mesías, su último filme, desplegando ante nosotros un discurso que parece salir espontáneamente de sus labios: en realidad, los poderosos tienen la fuerza y la ejercen porque son en esencia débiles, y esta debilidad proviene del miedo que los domina. Creen estar rodeados de enemigos por todas partes. La gente que hace daño se lo hace sobre todo a sí misma, porque el recuerdo de sus iniquidades les hará enloquecer. 
Rossellini necesita a Sócrates para trasladar la idea de la virtud, esto es, del conocimiento. Ya decía John Keats que la belleza es verdad, la verdad es belleza: eso es cuanto sabemos -y debemos saber- sobre la tierra. Sócrates es especialmente un personaje creado por Platón, una metáfora de la verdadera conducta humana, un salvador que nos redime ante las injusticias y ante la muerte. El hombre que gobierne una ciudad tiene que tener esa virtud porque si es un hombre de valía servirá de ejemplo a todos. Hubo momentos en que los ciudadanos le preguntaban al filósofo por qué no se dedicaba a la política en vez de hablar tanto, y Sócrates siempre decía lo mismo: si me dedicara a la política, ya estaría muerto. Es más, si hubiera hombres justos gobernando la ciudad a los ciudadanos no les importaría dar su vida por defenderla. Pero en general los Estados reclutan a sus soldados entre extranjeros y acólitos porque no son hombres justos.

La lectura que hace Rossellini de Sócrates fundamenta la idea de que éste hubo de defenderse de la crítica de estar proselitizando jóvenes, hasta el punto de que el anciano les responde con una pregunta: ¿y hasta qué edad es joven un hombre? Lo extraño es que Sócrates se viera envuelto en el juicio que le llevó a la muerte una vez recuperada la democracia tras el desgraciado período de los treinta tiranos. A partir de entonces cada griego dominaba la ciudad al menos un día en su vida, única forma de que la política no se volviera peligrosa. Sócrates volvió al ágora y su reputación creció entre los jóvenes. Les decía que el alma se queda ciega si se quiere descubrir la verdad en los detalles, y que dirigir los asuntos de un Estado es un asunto muy difícil: no me dedico a la política porque durante el juicio a los generales comprendí que el lugar de aquel que lucha contra la injusticia está en medio de la masa y no en los cargos públicos.

Sócrates sería un hombre necesario hoy en medio de tanta epopeya demagógica sobre la patria: mi patria es Atenas, eso lo demostré en el campo de batalla, pero también suelo pensar que la Tierra es inmensa, con multitud de pueblos dispersos en torno al mar como ranas en un estanque. La sabiduría no es sólo ateniense; la fuerza, sólo espartana; la prudencia, corintia. Soy ateniense, pero también soy un hombre, como todos los hombres de la tierra. Las tradiciones tienen sentido sólo si las podemos apreciar en su significación. Hay que desconfiar de los hábitos. 
El rechazo de Rossellini al cine es el mismo rechazo de Sócrates a la escritura. Una ironía metafísica. En el filme el personaje está más de acuerdo con el rey que con el dios, pues la escritura destruiría la verdadera memoria que es interior y que todo hombre verdadero lleva dentro de sí mismo (Lledó, 1992), no como ahora que se organizan grandes fastos para resaltar oscuros y falsos textos escritos desde el odio, y no desde la razón. ¿Qué se podrá responder a las citas?

-Tú contrapones, entonces, el discurso vivo, que vibra con las palabras, a la escritura que es imagen del discurso.

-Así es: es posible creer que los escritos hablan inteligentemente, pero intenta interrogarlos. Sólo pueden repetirse. Una vez escritos los discursos pasan de mano en mano indiferentemente, sin que pueda distinguirse uno débil, de uno inteligente. $Y$ si los escritos te atacan si te acusan injustamente, resultará imposible hacerle entender razones.

Finalmente, Sócrates acude a la orquestra donde tuvo lugar su juicio. Aún se oía el eco del clamor suscitado por sus palabras, palabras que sus alumnos Platón y Jenofonte recogerían en forma de una apologética que todo hombre de bien debería leer alguna vez.

-Me hice muchos enemigos porque a menudo son los más encumbrados los que tienen mayores defectos, pero yo permanezco al servicio del dios que me obliga a buscar la verdad aun cuando esta búsqueda me ha revelado que cuantos pretenden ser sabios no lo han de ser en modo alguno.

$\mathrm{Al}$ ser acusado de ateo, Sócrates inicia una defensa llena de un coraje y de una profundidad incontrovertible:

-¿Es posible creer en la realidad de las acciones humanas sin creer en la realidad de los hombres? ¿Es posible creer en la equitación sin creer en la existencia de los caballos? ¿Entonces se puede creer en la manifestación de un poder sobrenatural sin creer en dicho poder?

Cuando supo la sentencia de sus jueces, que lo acababan de condenar a muerte, Sócrates tuvo una reacción ejemplar. Se dirigió a sus conciudadanos, y dijo aquellas emotivas palabras que hemos de volver a repetir:

-Ciudadanos, si hubierais esperado un poco, la muerte os habría liberado de Sócrates por sí sola. Saldremos de esta asamblea: yo, condenado a muerte; y 
vosotros, mis jueces, condenados por la verdad. Y toda vuestra vida quedaré marcada por la injusticia que ahora cometéis.

\section{Bergman y la imagen}

En general, los artistas que poseen un mundo interior, conocen los lazos que unen sus obras aunque medie entre ellas el tiempo inexorable y la vida acabada. Bergman persigue, como todos los grandes hombres, la expresión. Matisse sostenía que no era capaz de distinguir el sentimiento que tenía de la vida y la manera con que la traducía. Bergman también explora la escena como si estuviera delante de un lienzo. Cuando se fija en un rostro, se para durante unos momentos ante él, y espera a que brote una luz interior en forma de línea congestionada por una emoción, pero decir que es el director de los primeros planos sin aprender a leer cómo ocupa el resto del espacio es no saber nada de él. En la Universidad había estudiado Arte igual que Murnau una generación anterior. Una composición siempre tendrá relación con su formato. La distancia entre la cámara y un actor se deriva del conjunto de la acción. El tamaño de un plano le produce al cineasta la misma controversia que a un pintor le produce el tamaño de una tela. Durante la realización de un filme Bergman tiene una vida que es la del filme, al mismo tiempo es su vida, porque no conoce otra mejor forma de vivir. El peligro del artista es que siente muchas veces la sensación de sentirse Dios, de sustituirlo. Hablan con esa determinación que tenían los dioses en Grecia. Cuando dirige a las actrices, Bergman las mira muy de cerca como los médicos que toman el pulso a sus enfermos. Es capaz de contemplar a una mujer tanto tiempo que diríase que está poseído por su persona -¿persona?-. Bergman actúa como el pintor que prefiere que la obra se imponga con todo su significado antes que el espectador conozca el tema. El arte de Bergman no es apacible, ni equilibrado; turba e inquieta. Todos los artistas -decía Matissellevan la huella de su época, pero los grandes artistas son aquellos en los que está marcada más profundamente. (Matisse, 1974). No sé si es el negro, como en Matisse, el color que predomina en Bergman. Lo cierto es que cuando deje el blanco y negro, se pasará violentamente al rojo - Esas mujeres, 1963, Gritos y susurros, 1971-, y ya no lo dejará (Hernéndez Les, 2006). 
"Si, por consiguiente quiero ser completamente sincero -escribió Bergmandebo considerar el arte 3 como algo intrascendente. Literatura, pintura, música, cine y teatro se procrean y se dan a luz a sí mismos. El movimiento visto desde fuera parece nerviosamente vital. No es más que el extraordinario afán de los artistas por proyectar para sí mismos y para el público la imagen de un mundo que ya no se preocupa de sus gustos o sus ideas. Si quiero seguir haciendo arte es por una razón muy sencilla. La razón es la curiosidad. Una insoportable curiosidad, ilimitada, jamás calmada, constantemente renovada, que me empuja hacia delante. Anoto, observo, ando con los ojos bien abiertos. Todo es irreal, fantástico, aterrorizador, o ridículo. Me paseo con mi objeto, que es sólo mío, capturado con mis propias manos y estoy alegre o melancólicamente ocupado". Se parece a la reflexión de Rilke: "el creador debe ser un mundo para sí mismo y encontrarlo todo en sí y en la naturaleza a que se ha adherido" (Rilke, 2003: 24).

\subsection{Secretos de un matrimonio/Saraband, paradigmas}

Deleuze tenía una concepción muy interesante acerca de la imagen. Venía a decir que una imagen es siempre percepción de uno mismo puesto que cada imagen movimiento es percepción de todos los movimientos que actúan sobre ella y de todos los movimientos por los cuales ella actúa sobre las otras imágenes. Una imagen así sería una aprehensión: prehende todos los movimientos que recibe y todos los movimientos que ejecuta (Deleuze, 1983). Si cada imagen es prehensión de algún movimiento que ya no está, entonces, una imagen es la captación de un presente, y el tiempo no sería otra cosa que una sucesión de intervalos. De hecho Deleuze llama intervalo al cerebro. Godard decía que el cine permite imprimir una expresión y, además, al mismo tiempo, expresar una impresión (Godard, 1980: 52),

Es curioso observar las diferencias entre Rossellini y Bergman a la hora de concebir la televisión. Lo que le interesa a Bergman de la televisión es servirse de ella, al menos en primera instancia, y en los primeros años en que se acerca a

\footnotetext{
3 El poeta Rainer María RILKE decía que la mayor parte de los hechos son indecibles, se cumplen en un ámbito que nunca ha hollado una palabra; y lo más indecible de todo son las obras de arte, realidades misteriosas, cuya existencia perdura junto a la nuestra que desaparece. En (2003). Cartas a un joven poeta. Madrid: Alianza Editorial, p. 21.
} 
ella. Pues si en Secretos de un matrimonio, 1973, no se muestra preocupado por la estética, treinta años después, es decir, cuando retoma a los mismos personajes principales en Saraband, el cuidado de la imagen ofrece todas las garantías de una puesta en escena que también contempla el escenario cinematográfico. Mientras que los filmes de Rossellini para la televisión no podían ser vistos en la pantalla grande, en parte porque Rossellini ya había sido ominosamente expulsado de ella, los de Bergman sí ofrecen, a excepción de Secretos...una composición que vale para los dos medios.

Hay una confusión a este respecto: hay quienes creen que Bergman filmó para el cine una versión particular después de haber enseñado por la televisión una serie de seis capítulos de cincuenta minutos cada uno, pero, en realidad, Bergman montó a partir de las imágenes de la serie una película de 165 minutos que según las circunstancias y países tiene la misma o una menor duración. Esto se debe al hecho de que Bergman filmó la serie en $16 \mathrm{~mm}$. Y luego fue hinchada o no en su explotación comercial. Lo que importa con todo, es que el director organizó la puesta en escena de Secretos...televisivamente.

En el fondo lo que vemos aquí es una conjunción de varios sistemas fundidos en la mirada y en la personalidad de un narrador completo, para quien no supone ninguna dificultad vincular el teatro, el cine y la televisión en una unidad excepcional, que nadie ha podido imitar ni intencionadamente. Al ser un cineasta que domina la geografía del primer plano, y sabe construir historias con muy pocos personajes, Bergman actúa, así, a la manera de la kamerspielfilme, y se inventa casi un nuevo género que podríamos denominar películas de cámara, igual que existe una música de cámara, y un teatro de cámara. Es decir, no la cámara como instrumento, sino como término escénico.

$\mathrm{Al}$ decidir la puesta en escena ésta ya le viene dada objetivamente por el medio: planos cortos de larga duración, escenarios de interiores singularmente simples, e iluminación cenital que permite rodar el filme muy rápidamente a partir de largos monólogos legibles en pantallas externas. Bergman reconoció haber escrito los diálogos en tres meses, pero filmarlos le llevó menos tiempo. Digamos, pues, que la puesta en escena de Secretos...está basada en los rostros de Liv Ullmann y Erland Josephson, y también en los diálogos, lo más difícil de un guión. 
La peculiaridad de esta película es que resulta imposible discernir argumento e historia, pues prácticamente toda la historia es revelada por los personajes a la manera de alguien que cuenta un relato. Hago esta distinción de una manera que, posiblemente, Genette aprobaría, pues llamo argumento a todo lo que muestra la acción, e historia a todo aquello que el espectador debe ir conociendo a medida que progresa el relato. Historia, sería, así, aquello que las imágenes no muestran, pero que son percibidas por las características ontológicas del relato fílmico.

A diferencia de la mayoría de los filmes aquí el argumento y la historia son casi la misma cosa, pues lo no mostrado es internalizado por los diálogos que escuchamos, de forma tal que son los personajes los que cuentan la historia; y el argumento, que siempre es una elección que el narrador selecciona de la historia que conoce, es tan liviano que es casi inexistente.

Marianne y Johan son, aparentemente, una pareja ejemplar. Tras diez años de casados Johan anuncia a su mujer que mantiene desde hace tiempo una relación amorosa con una ex alumna, con la que pretende estabilizar su relación. Al principio a Marianne le cuesta asimilar la noticia, pero después toma la iniciativa y prepara, como abogada que es, el contrato de divorcio, que a Johan le resulta difícil de firmar pasado el tiempo. Las relaciones de Johan con su amante parecen llegar a su término, y ambos conocen diferentes experiencias con distintas parejas. Pero durante todo este tiempo Marianne y Johan han seguido viéndose a escondidas, y cuando, finalmente, se casan con sus últimas parejas respectivas, viven un renovado amor adúltero en la misma casa de campo que adquirieron al principio de su relación y en la que sufrieron la ruptura.

Como se ve, el tiempo del relato es muy largo, hasta de 10 años y, sin embargo, la pareja aparece ante el espectador dentro de los mismos escenarios e interiores: la casa de campo, la casa de Marianne, la oficina, y poco más. Bergman describe casi todas las emociones del amor de una manera sabia y trascendental, desde la alegría al dolor, su satisfacción, su insatisfacción, la comprensión y el odio, la cercanía, y el rechazo, todo en una larga gama de situaciones dentro de un espacio físico tan reducido que resulta casi imposible asimilarlo. 
La forma en que Bergman organiza la resolución de los problemas espaciales invitaría a cualquier realizador de televisión a abrazar el medio sin ningún complejo. Secretos... debería de contemplarse como el grado cero de una tv/movie. Eficacia, abaratamiento, y calidad. Bergman recurre a Antonioni para encuadrar al matrimonio cuando Johan se despide de Marianne, y ésta permanece al fondo del marco de la puerta que reduce el espacio visual a un simple y estirado rectángulo. Y supera la dialéctica plano/contraplano en los diálogos larguísimos que mantiene la pareja componiendo las posiciones de los actores en ángulo recto o, simplemente, filmando de perfil a uno de los dos si están muy cerca. Al principio, cuando estalla el conflicto Bergman prioriza el rostro de Marianne, pero a medida que avanza la acción, puede colocarlos juntos, hablando sin que se miren, o puede filmarlos rompiendo de nuevo la dinámica del plano/contraplano al hacer que los personajes hablen mirando a un contracampo visual imaginario. El eje de la cámara es casi siempre inamovible, pero si cambia Bergman no efectúa desplazamientos significativos, ni panorámicas. Usa el zomm, igual que Rossellini, por razones pragmáticas, aunque sin abusar.

Si fuera del todo una ficción Bergman no necesitaría recurrir de nuevo a Erland Josephson y Liv Ullman treinta años después. Pero ellos, las personas que ellos son, han envejecido y vuelven a encontrarse con nosotros. Este efecto verdad se halla situado también a otros niveles: en la forma en que de nuevo Ullmann se dirige a los espectadores en primera persona y mirando a la cámara. Es el mismo efecto ya utilizado en Secretos de un matrimonio, pero esta vez la cosa va más allá, porque en la secuencia siguiente, y en plena acción dramática, Liv Ullman vuelve a dirigirse al espectador de una manera todavía más cómplice. Al fin y al cabo no estamos sólo delante del personaje que representa, sino delante de la actriz. Pero no sólo es Ullman quien nos mira y habla. Hay todavía una mayor invocación al espectador cuando Karin nos mira desde la almohada de su cama durante más de cinco minutos mientras escuchamos el monólogo de su padre que está justo detrás de ella, desarbolando y superando el viejo y erótico mito de Lot y sus hijas4. Esta composición cinematográfica no es fácil hallarla en

\footnotetext{
4 Lot muestra su lascivia debajo del árbol renacentista, pero una de sus hijas refleja en su rostro la felicidad tendida sobre su pecho, mientras sus hermanas esperan el turno de aposentarse junto al padre.
} 
el cine y revela la enorme capacidad creativa que siempre tuvo Bergman para originar nuevas representaciones y utilizar un punto de vista que revoluciona lo estético en toda su amplitud. Börge Ahlsted realiza una actuación tan magistral que cualquier interpretación freudiana se vendría abajo estrepitosamente porque a Bergman, en su inmensa capacidad intelectiva, no le interesan las causas del dolor humano ni las fechorías del monstruo, la Cosa y el inconsciente, sino ese monstruo y ese ángel que todos llevamos dentro.

La película tiene más argumento que su relativa "primera parte”, pero la presencia de la historia aquí también es muy importante. La abogada visita a su exmarido, un octogenario, que ha renunciado a la Universidad porque una tía suya le ha transmitido su herencia, y Johan se ha venido a vivir al bosque. Johan sólo convive con su nieta Karin, desolada por haber perdido recientemente a su madre, Anne, y odia a su hijo, Henrik, que al enviudar anula la personalidad de su hija. Naturalmente, estos personajes son nuevos, y producen una aristotélica peripecia en la nueva trama. Marianne es de algún modo el daimón de Bergman abriendo las significativas puertas de la casa, y transportando el relato físicamente, tanto como autor implícito como cuanto espectadora que nos representa.

Hay aquí algo misterioso y sorprendente, pues cabría hablar de una película intermedia, que es toda la historia que los espectadores podemos formarnos a partir del argumento e historia de Saraband, esos treinta años no contados ni filmados pero que los espectadores intuimos con el conocimiento que ahora obtenemos de las informaciones que nos suministran Johan y Marianne, de forma retrospectiva.

Ahora la vida ya no es la vida de una pareja en apuros, que se ha querido y se ha engañado, y se ha vuelto a querer. Ahora nos hallamos ante la historia de una familia de tres generaciones, en donde la figura del padre es la menos freudiana que pudiéramos establecer. No así el hijo, Henrik, el zaherido, y la visión sobre la nieta supone una especie de restablecimiento del orden jerárquico. Si allí estaba el amor y el dolor, aquí se instala el dolor y el dolor y, finalmente, el piadoso afecto y la piadosa comprensión de la idea de que han vivido, de que hemos vivido. El plano final de los viejos, desnudos, aceptándose es un plano que explica muchas cosas. 
Y a la teoría de la voz del autor ya expuesta por Company (1981: 24 y ss). Se trataría de la relación autor-obra, que fue malinterpretada en su día por culpa no tanto de la insana mente popular como cuanto de las relaciones que entonces mantenían el director y la actriz. Bergman utiliza recursos plenamente televisivos. Si en Secretos de un matrimonio comenzaba por presentar a los personajes delante de una cámara de televisión, el directo, aquí presenta a una anciana, Liv Ullmann, ante la cámara cinematográfica mirando directamente al objetivo. Este efecto realidad que trata irónicamente de desplazar el carácter ontológico del cine convierte la relación cine/televisión en un ente inseparablemente estructural, pues todavía el director conoce las condiciones y los objetivos para los que trabaja, así como un conocimiento del público, un referente que ha sido sacado de las salas para ver en casa; primero, televisión y, después, cine.

Bergman es un cineasta que se acopla bien a la televisión porque ama el sentido de la kamerspielfilme, de una manera tal que puede componer largos planos de duración con encuadres muy cortos, si bien aquí, a diferencia de la anterior, gusta más de planificar la escena en planos medios, casi generales, como cuando Henrik se descontrola y trata de besar apasionadamente a su hija. Es un filme de contactos físicos. En la Iglesia Marianne y Henrik están muy próximos. En la casa de campo, al comienzo, Johan y Marianne se abrazan. Karin busca el rostro de Marianne. Y en la casa de su padre Karin habla y toca a Henrik. Pero no es desde el primer plano bergmaniano, sino desde planos de naturaleza vinciana, aplanados, con la cámara muy baja, casi a la manera de los clásicos japoneses.

Bergman no explica a qué grado de incestuosidad llegan las relaciones del padre y de la hija. Karin sabe que tiene derecho a marcharse de casa, y aceptar la propuesta del amigo del abuelo, que le facilitaría la marcha a Leningrado y un probable triunfo en una orquesta de elevado nivel. También sabe que ama a su padre, un hombre débil que llora todos los días por la esposa perdida, y que ve en la hija, como Lot, la trágica extensión de su enfermiza pulsión. En realidad, Henrik ama a una ausente, y Karin lo sabe. Lo de Karin no es deseo, es sólo compasión. Y lo de Henrik es la totalidad mitológica, eso que alcanza por igual lo racional y lo irracional, lo justo y lo desmedido, el deseo y el amor. Es un 
hombre terrible, lleno de dolor. Un juez culto no lo arrestaría. Pero tendría que ser un juez sueco.

$\mathrm{Y}$ aquí vuelvo a Company. No es fácil asociar pesimismo existencial con conformismo. Él así lo hace en el texto mencionado. Bergman no es conformista, porque los sentimientos y su tratamiento no son asunto de la política sino del arte, y su pareja no es exactamente una pareja burguesa en el sentido que aquí dábamos al término en los años del franquismo. Hoy, paradójicamente, ningún izquierdista habla de la burguesía o de lo burgués, pues podría cogerse de las manos. Además, el conocimiento no es condena, sino dolor. No hay ensimismamiento burgués en las atroces disputas suecas que mantienen Marianne y Johan cuando son jóvenes. La ficción como tal -escribe Company- queda reducida a mera retórica o vulgar melodrama. No. Estamos ante un docudrama, tanto en la primera parte, como en la segunda, treinta años después. Estamos, literalmente ante una representación en la que sus protagonistas actúan delante de un espejo. El espejo puede ser el espectador, clave decisiva de todo docudrama discursivo. O puede ser el antagonista al que replican textualmente. $\mathrm{O}$ ante ellos mismos, que se saben vigilados por el hecho de que conozcamos su pasado.

\section{Conclusiones}

Tenemos pues que si en Rossellini el paradigma televisivo se constituye en forma de Historia, es decir, de revisitación histórica, en Bergman el paradigma se constituye precisamente en forma de docudrama. Ficción e Historia por un lado, ficción/ docudrama, por el otro, pero fíjense que en ambos casos los dos cineastas aprueban el método didáctico, el uso didáctico del cine para acceder estéticamente al espectador. Ahora bien, ¿qué debemos comprender por didáctico en dos cineastas que se han interesado por el hombre, por ese hombre que está sólo ante las estrellas o ante sí mismo? Todo discurso, incluido el didáctico necesita de un constructo. Rossellini no acepta el documental. Necesita el documental también de una mirada, y la mirada es a la vez una constructo. Enseñar es también mostrar, y mostrar lleva a la representación. India no tiene nada que ver con los diez documentales que Rossellini rodara 
previamente. ¿Qué es representar? Representar es revelar el alma que para los viejos materialistas es el cuerpo. Y el cuerpo es el alma.

En el Sócrates rosselliniano la traslatio platónica es inconmensurable. Allí se sintetiza la Apología, básicamente, y otros textos de Platón, como ya se ha dicho; y aquí se articula una forma de psicoanálisis en donde la ficción y la confesión van de la mano. Antaño se diría lo real, pero lo cierto es que muy pocos cineastas saben articular tan estrechamente dos expresiones que parecían, en un principio, muy alejadas entre sí. Si en Bergman produce una extraña impresión es porque Bergman nunca le hizo ascos a la representación, suceso que viene de la mitología, antes que del teatro, y porque acaso sea el más trascendental de los cineastas que nos haya legado el cine. Por otra parte, es consustancial a Rossellini una forma sublime de entender la Historia y la vida. Su creencia en el Hombre es casi enfermiza, y su "agnosticismo" está lleno de esperanza, una esperanza más próxima, si se quiere, a la espera, y que roza, sin tocarla, la fe.

Bergman sigue a Hegel más que Rossellini. El filósofo alemán escribió en sus diarios que tengo que hallar una verdad para mí, encontrar esa idea por la que quiero vivir y morir (Merchán, 2002). La invisibilidad entre ficción y personalismo descansa en la idea expuesta por Vicente Simón Merchán de que lo personal es lo real, que tanta influencia tendrá progresivamente en los existencialistas posteriores: el hombre se elige a sí mismo como existente, vive en el dominio de lo que Schiller denominó el estadio estético (Schiller, 1991), un estadio en donde el único compromiso que se puede y debe atender es la momentaneidad.

El proceso de ese hombre real pasaría primero por el estadio estético, alcanzaría después el ético y acabaría elevándose al verdadero estadio, el religioso. Tanto en la obra de Rossellini como en la de Bergman hay obras donde casi puede seguirse este proceso. En Sócrates es claro, y acaso en Los comulgantes también. Hablar de pesimismo en Bergman es, pues, una contrariedad, ya que es junto a Rossellini uno de los pocos hombres que han pasado por esta experiencia gradual. Los personajes de Bergman son como el individuo hegeliano, una conciencia infeliz, sin embargo, el pesimismo es otra cosa. No es conciencia asegurada, sino que, simplemente, depende del humor; no es un verdadero estado de ánimo. La conciencia infeliz delata al hombre en su 
verdadera esencia, separado y aislado de todo. Bergman trasluce en todas sus películas la vieja idea de Kierkegaard según la cual el hombre se siente incómodo con Dios. Dios no comunica directamente con él, y el hombre, así, accede al tercer estadio, el religioso, en el que el hombre sufre un absurdo.

Ambos cineastas están más cerca de la realidad que de la ficción porque consideran la realidad como algo más fantástico que la ficción. El hombre es todo, como señaló Rossellini: lo más importante es verlo actuar en cualquier circunstancia5. En Bergman, por el contrario, todas las circunstancias conducen al ser, es decir, al sentido, qué hago aquí. Mientras Rossellini tiende a desdramatizar, Bergman pone énfasis en la dramatización, esto, en la representación. Si aquel no necesita actores, éste sí los necesita. Sólo que los actores en Bergman son muy personalistas: parecen haber vivido lo que interpretan, como si al interpretarlo lo hicieran por segunda vez.

No deja de ser curioso que Rossellini empezara haciendo películas experimentales y acabara realizando filmes de ficción para la televisión, mientras Bergman empezó haciendo filmes psicológicos y acabó haciendo docudramas genealógicos para este mismo medio, como Saraband (Puigdomenech, 2004). Aunque el trabajo analítico es más propio de la literatura que del cine, se obtiene la impresión viendo las películas de ambos que desmenuzan la realidad idea por idea, y organizándolas, separándolas, como si no tuvieran delante de sí las múltiples significaciones de la imagen en un solo plano, sino una sola significación, y luego otra significación, y, finalmente, todas las significaciones en su conjunto.

Rossellini no es el inventor del cinema verité, ni su defensor a ultranza. De hecho tuvo una fuerte discusión con Rouch a propósito de La Punition. Rouch partió, como Rossellini en busca de la verdad, intentando encontrarla en las personas. Para Rossellini el cine verdad es un absurdo: no se puede confiar en la casualidad, pues para no caer en un vulgar documental hay que elaborar las películas.

Otra importante distinción entre Rossellini y Bergman es que el primero no veía diferencias entre el cine y la televisión desde un punto de vista técnico, mientras que el segundo sí las vio, de tal forma que, cuando hubo de hacer el traslado, 
pensó en planificaciones más cortas, más cercanas a los actores, privilegiando los interiores frente a los exteriores, si bien no deja de ser cierto que Bergman siempre fue un cineasta que tendió a los interiores motivado, acaso, por la elección de sus temas.

\section{Referencias bibliográficas}

ANDREW, D. (1983). Las principales teorías cinematográficas. Barcelona: Gustavio Gili.

ARENDT, Hanna (2005). La condición humana. Barcelona: Paidós.

BARTHES, Roland (1972). Crítica y verdad. Buenos Aires: Siglo XXI.

BAZIN, André (1962). Qué es el cine. Madrid. Rialp

BERGMAN, Ingmar (1992). Imágenes. Barcelona: Tusquets.

COMPANY, Juan Miguel (1981). Bergman. Barcelona: Barcanova.

DEBRIX, Jean R. (1980). "El efecto de la TV. sobre la estética cinematográfica". En ROMAGUERA I RAMIO, y ALSINA THEVENET, Homero (1985). Textos y manifiestos del cine. Barcelona: Fontamara.

DELEUZE, Gilles (1983). Cinéma 1. L’image-mouvement, Paris: Minuit.

GODARD, Jean-Luc (1980). Introducción a una verdadera Historia del Cine. Madrid: Ediciones Alphaville.

GUARNER, José Luis (1973). Roberto Rossellini. Barcelona: Editorial Fundamentos.

HERNÁNDEZ LES, Juan A. (2003). Cine e literatura, a especificidade da imaxe visual. A Coruña: Xunta de Galicia/CGAI, 1993 (existe versión en portugués. Porto: Campo das Letras).

HERNÁNDEZ LES, Juan A. (2006). "Unha sonata para dous instrumentos". En AMORÓS, Anna, y NOGUEIRA, Xosé, Xéneros cinematográficos? Aproximación e reflexións. Santiago de Compostela: Universidad

JASPERS, Karl (1995). Lo trágico. Málaga: Agora.

KIERKEGAARD, Sören (2002). Temor y temblor. Madrid: Alianza editorial.

KUHN, Thomas S. (1975). La estructura de las revoluciones científicas. Madrid: Fondo de Cultura Económica.

LENNE, Gerard (1971). La muerte del cine (film/revolución). Barcelona: Anagrama.

LLEDÓ, Emilio (1992). El silencio de la escritura. Barcelona: Círculo de lectores.

LEOPARDI, Giacomo (1990). Zibaldone de pensamientos. Barcelona: Tusquets. MATISSE, H. (1974). Sobre arte. Barcelona: Ed. Barral. 
Mc CONNELL, Frank D. (1977). El cine y la imaginación romántica. Barcelona: Gustavo Gili

MERCHÁN, Vicente Simón (2002). "Estudio preliminar", en KIERKEGAARD, Sören. Temor y temblor. Madrid: Alianza editorial

OSBORNE (1972). Lo estético. Fondo de Cultura Económica: Méjico.

PUIGDOMENECH, Jordi (2004). Ingmar Bergman, el último existencialista. Madrid: Ediciones JC.

QUINTANA, Angel (1996). Mediación y transparencia. Un método didáctico para la utopía televisiva de Roberto Rossellini. Barcelona: Episteme.

REQUENA, Jesús G. (2003). "Del soberano bien”, en Trama y Fondo, no 15.

RILKE, Rainer Maria (2003). Cartas a un joven poeta. Madrid: Alianza Editorial.

ROMAGUERA I RAMIO, y ALSINA THEVENET, Homero (1980). Fuentes y documentos del cine. Barcelona: Gustavo Gili.

ROMAGUERA I RAMIO, y ALSINA THEVENET, Homero (1985). Textos y manifiestos del cine. Barcelona: Fontamara.

SARRIS, Andrew (1969). Entrevistas con directores de cine. Madrid: Novelas y Cuentos.

SCHILLER, Johann Christoph Freidrich (1991). "Cartas sobre la educación estética", en Escritos sobre estética. Madrid: Tecnos.

TARKOVSKI, A. (1991). Esculpir en el tiempo. Madrid: Rialp.

TRIAS, Eugenio (1973). Drama e identidad, Madrid: Alianza Editorial. 